\title{
RANCANG BANGUN SISTEM INFORMASI MANAJEMEN KEPEGAWAIAN DI FAKULTAS TEKNIK UNIVERSITAS LAMBUNG MANGKURAT
}

\author{
Maya Amalia ${ }^{1)}$, Muhammad Alkaff ${ }^{2)}$, Yuslena Sari ${ }^{3)}$ \\ ${ }^{1}$ Department of Civil Engineering, Lambung Mangkurat University \\ ${ }^{2}$ Department of Information Engineering, Lambung Mangkurat University \\ ${ }^{3}$ Department of Information Engineering, Lambung Mangkurat University \\ e-mail: maya ftunlam@yahoo.co.id ${ }^{1)}, \underline{\text { m.alkaff9@gmail.com }}^{2)}$,yuzlena@gmail.com ${ }^{3)}$
}

\begin{abstract}
ABSTRAK
Penerapan sistem informasi manajemen dalam lembaga negara atau organisasi publik, akan memudahkan lembaga tersebut dalam mengelola berbagai data yang diperlukan untuk menjadi informasi yang bermanfaat, baik bagi internal organisasi maupun bagi kalangan yang berada diluar organisasi. Fakultas Teknik Universitas Lambung Mangkurat dalam hal ini masih memiliki kekurangan dalam melakukan pendataan data-data yang terkait dengan tenaga pendidik dan tenaga kependidikan, terutama berkaitan dengan data penelitian dan pengabdian masyarakat. Proses pendataan di Fakultas Teknik Universitas Lambung Mangkurat masih dilakukan secara manual dan tidak terkomputerisasi. Perancangan dan pembangunan sebuah sistem informasi kepegawaian tentu akan sangat membantu dalam mempercepat proses pendataan data-data yang berkaitan dengan tenaga pendidik dan tenaga kependidikan. Diharapkan dengan adanya sistem informasi ini, data tenaga pendidik dan tenaga kependidikan di lingkungan Fakultas Teknik Universitas Lambung Mangkurat dapat lebih tertata dengan rapi sehingga memudahkan dalam pelaksanaan monitoring dan evaluasi di bidang kepegawaian.
\end{abstract}

Katakunci:, Data, Kepegawaian, Sistem, Informasi

\section{ABSTRACT}

Implementation of management information sistems in state institutions or public organizations, will allow it to manage a variety of data needed to be valuable information for both internal organization and for those who are outside the organization. Faculty of Engineering, University Mangkurat in this case still has shortcomings in performing data collection associated with educators and education personnel, mainly deals with research and community service. The data collection process at the Faculty of Engineering, University Mangkurat still done manually and not computerized. The design and construction of a sistem of personnel information would be very helpful in speeding up the process of collection of data pertaining to educators and education personnel. Hopefully, by the information sistem, data educators and educational staff in the Faculty of Engineering, University of Mangkurat can be neatly arranged so as to facilitate the implementation of monitoring and evaluation in the field of personnel.

Keywords: Data, Personnel, System, Information

\section{I. PENDAHULUAN}

Pada era informasi saat ini, salah satu permasalahan utama adalah bagaimana mengolah data sedemikian rupa untuk menghasilkan informasi yang berguna, dan mudah digunakan oleh pengguna informasi. Proses pengarsipan dan pengelolaan data yang tidak terkomputerisasi akan membuat informasi yang ada pada data tidak termanfaatkan sebagaimana mestinya termasuk dalam hal ini adalah data yang berkaitan dengan kepegawaian.

Menurut The Liang Gie, Administrasi Kepegawaian adalah segenap aktivitas yang bersangkutan dengan masalah penggunaan tenaga kerja untuk mencapai tujuan tertentu. Masalah pokoknya terutama berkisar pada penerimaan, pengembangan, pemberian balas jasa dan pemberhentian (Imron, 2008).

Fakultas Teknik merupakan unit kerja yang berada dibawah Universitas Lambung Mangkurat yang didalamnya bernaung tenaga pendidik dan tenaga kependidikan yang harus dimonitor dan dievaluasi kinerjanya. Pengelolaan data sumber daya manusia di Fakultas Teknik Universitas Lambung Mangkurat dalam hal ini masih belum terkomputerisasi sehingga terdapat kesulitan dalam melakukan monitoring dan evaluasi kinerja tenaga pendidik dan tenaga kependidikannya.

Sistem informasi kepegawaian merupakan suatu sistem yang terstruktur untuk membantu pendataan, pengelolaan, dan monitoring data kepegawaian guna mengatasi permasalahan-permasalahan yang dimulai dari sudut pandang kepegawaian yang sesuai dengan kebutuhan institusi, membantu pimpinan dalam melakukan pengambilan keputusan, dan juga untuk memenuhi pelaksanaan kebijakan pemerintah dalam 
institusi. Sistem informasi manajemen kepegawaian dalam kajian penelitian ini lebih memfokuskan pada proses, penyusunan dan pengolahan data kepegawaian yang berkaitan dengan data-data kinerja dosen yang berada di lingkungan Fakultas Teknik Universitas Lambung Mangkurat.

\section{II. TINJAUAN PUSTAKA}

\section{A. Sistem Informasi}

Suatu sistem informasi (Information Sistem) adalah sekelompok komponen yang berinteraksi untuk menghasilkan informasi (Kroenke, 1990). Dengan kata lain, sistem informasi adalah suatu sistem buatan manusia yang secara umum terdiri atas sekumpulan komponen berbasis komputer dan manual yang dibuat untuk menghimpun, menyimpan, dan mengola serta menyediakan informasi untuk menunjang pengambilan keputusan dan pengawasan dalam suatu organisasi serta membantu manajemen dalam mengambil keputusan. Penyediaan informasi yang cepat, tepat, dan akurat membutuhkan suatu sistem informasi manajemen yang terkomputerisasi.

\section{Komponen Sistem Informasi}

1. Komponen input input merupakan data yang masuk ke dalam sistem informasi.

2. Komponen model kombinasi prosedur,logika,dan model matematika yang memproses data yang tersimpan di basis data dengan cara yang sudah di tentukan untuk menghasilkan keluaran yang diinginkan.

3. Komponen output output informasi yang berkualitas dan dokumentasi yang berguna untuk semua tingkatan manajemen serta semua pemakai sistem.

4. Komponen teknologi teknologi merupakan alat dalam sistem informasi, teknologi digunakan untuk menerima innput, menjalankan model, minyimpan dan mengakses data, menghasilkan dan mengirimkan output dan memantu pengendalian sistem.

5. Komponen basis data merupakan kumpulan data yang saling berhubungan yang tersimpan di dalam komputer dengan menggunakan software database.

6. Komponen kontrol pengendalian yang dirancang untuk menanggulangi gangguan terhadap sistem informasi.

\section{B. Model Waterfall}

Metode Waterfall merupakan metode klasik yang bersifat sistematis dan terurut dalam perancangan dan pembangunan perangkat lunak (Pressman, 2005). Model ini melakukan pendekatan secara sistematis dan urut mulai dari level kebutuhan sistem lalu menuju ke tahap analisis, desain, coding, testing / verification, dan maintenance. 


\section{Waterfall Model (Diagram)}

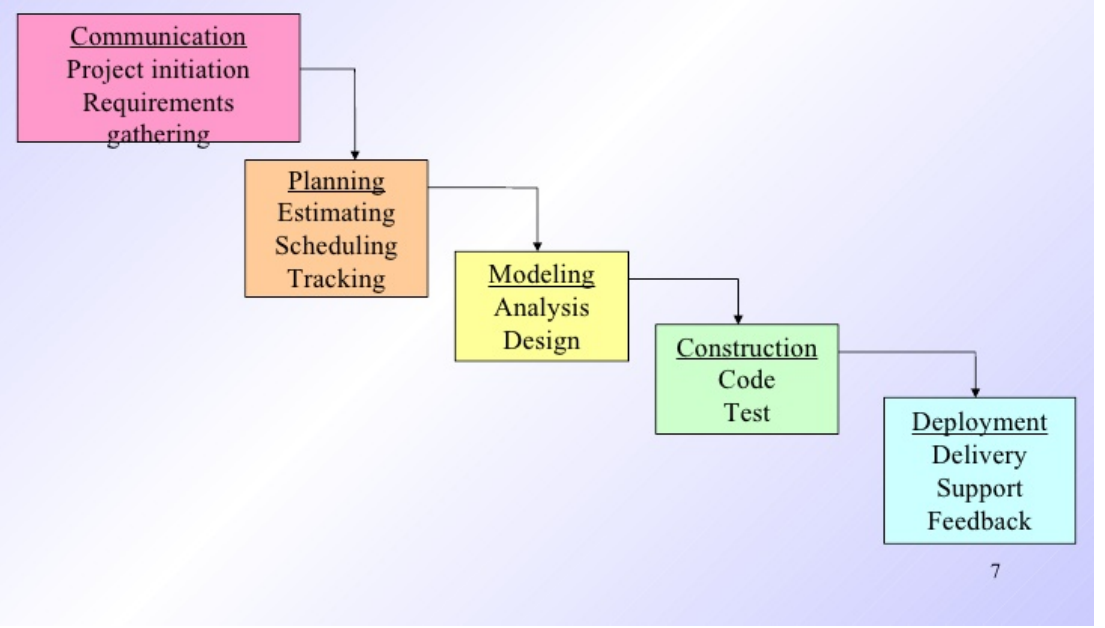

Gambar 1. Model Waterfall

Disebut dengan waterfall karena tahap demi tahap yang dilalui harus menunggu selesainya tahap sebelumnya dan berjalan berurutan. Model ini bagus untuk digunakan apabila kebutuhan perangkat lunak sudah jelas, definisi produk stabil, dan teknologi yang digunakan dapat dimengerti. Roger S. Pressman memecah model ini menjadi 6 tahapan meskipun secara garis besar sama dengan tahapan-tahapan model waterfall pada umumnya.

\section{Tahapan Metode Waterfall}

1. Sistem / Information Engineering and Modeling. Permodelan ini diawali dengan mencari kebutuhan dari keseluruhan sistem yang akan diaplikasikan ke dalam bentuk perangkat lunak. Hal ini sangat penting, mengingat perangkat lunak harus dapat berinteraksi dengan elemen-elemen yang lain seperti hardware, database, dsb. Tahap ini sering disebut dengan Project Definition.

2. Software Requirements Analysis. Proses pencarian kebutuhan diintensifkan dan difokuskan pada perangkat lunak. Untuk mengetahui sifat dari program yang akan dibuat, maka para software engineer harus mengerti tentang domain informasi dari perangkat lunak, misalnya fungsi yang dibutuhkan, user interface, dsb. Dari 2 aktivitas tersebut (pencarian kebutuhan sistem dan perangkat lunak) harus didokumentasikan dan ditunjukkan kepada pelanggan.

3. Design. Proses ini digunakan untuk mengubah kebutuhan-kebutuhan diatas menjadi representasi ke dalam bentuk "blueprint" perangkat lunak sebelum coding dimulai. Desain harus dapat mengimplementasikan kebutuhan yang telah disebutkan pada tahap sebelumnya. Seperti 2 aktivitas sebelumnya, maka proses ini juga harus didokumentasikan sebagai konfigurasi dari perangkat lunak.

4. Coding. Untuk dapat dimengerti oleh mesin, dalam hal ini adalah komputer, maka desain tadi harus diubah bentuknya menjadi bentuk yang dapat dimengerti oleh mesin, yaitu ke dalam bahasa pemrograman melalui proses coding. Tahap ini merupakan implementasi dari tahap design yang secara teknis nantinya dikerjakan oleh programmer.

5. Testing / Verification. Sesuatu yang dibuat haruslah diujicobakan. Demikian juga dengan perangkat lunak. Semua fungsi-fungsi perangkat lunak harus diujicobakan, agar perangkat lunak bebas dari error, dan hasilnya harus benar-benar sesuai dengan kebutuhan yang sudah didefinisikan sebelumnya.

6. Maintenance. Pemeliharaan suatu perangkat lunak diperlukan, termasuk di dalamnya adalah pengembangan, karena perangkat lunak yang dibuat tidak selamanya hanya seperti itu. Ketika dijalankan mungkin saja masih ada kesalahan kecil yang tidak ditemukan sebelumnya, atau ada penambahan fitur-fitur yang belum ada pada perangkat lunak tersebut. Pengembangan diperlukan ketika adanya perubahan dari eksternal perusahaan seperti ketika ada pergantian sistem operasi, atau perangkat lainnya. 


\section{UML}

UML (Unified Modeling Language) adalah sekumpulan alat yang digunakan untuk melakukan abstraksi terhadap sebuah sistem atau perangkat lunak berbasis objek. UML bersifat ringkas dan mudah dipahami (Raymond, 2004) oleh karena itu UML juga menjadi salah satu cara untuk mempermudah pengembangan aplikasi yang berkelanjutan. Aplikasi atau sistem yang tidak terdokumentasi biasanya dapat menghambat pengembangan karena developer harus melakukan penelusuran dan mempelajari kode program. UML juga dapat menjadi alat bantu untuk transfer ilmu tentang sistem atau aplikasi yang akan dikembangkan dari satu developer ke developer lainya.

\section{III. ANALISA DESAIN SISTEM}

A. Use case Diagam

Use case diagram adalah gambaran graphical dari beberapa atau semua actor, use case, dan interaksi diantara komponen-komponen tersebut yang memperkenalkan suatu sistem yang akan dibangun. Use case diagram menjelaskan manfaat suatu sistem jika dilihat menurut pandangan orang yang berada di luar sistem. Diagram ini menunjukkan fungsionalitas suatu sistem atau kelas dan bagaimana sistem tersebut berinteraksi dengan dunia luar. Use case diagram yang digunakan pada Sistem Informasi Kepegawaian Fakultas Teknik Universitas Lambung Mangkurat dapat dilihat pada Gambar 2

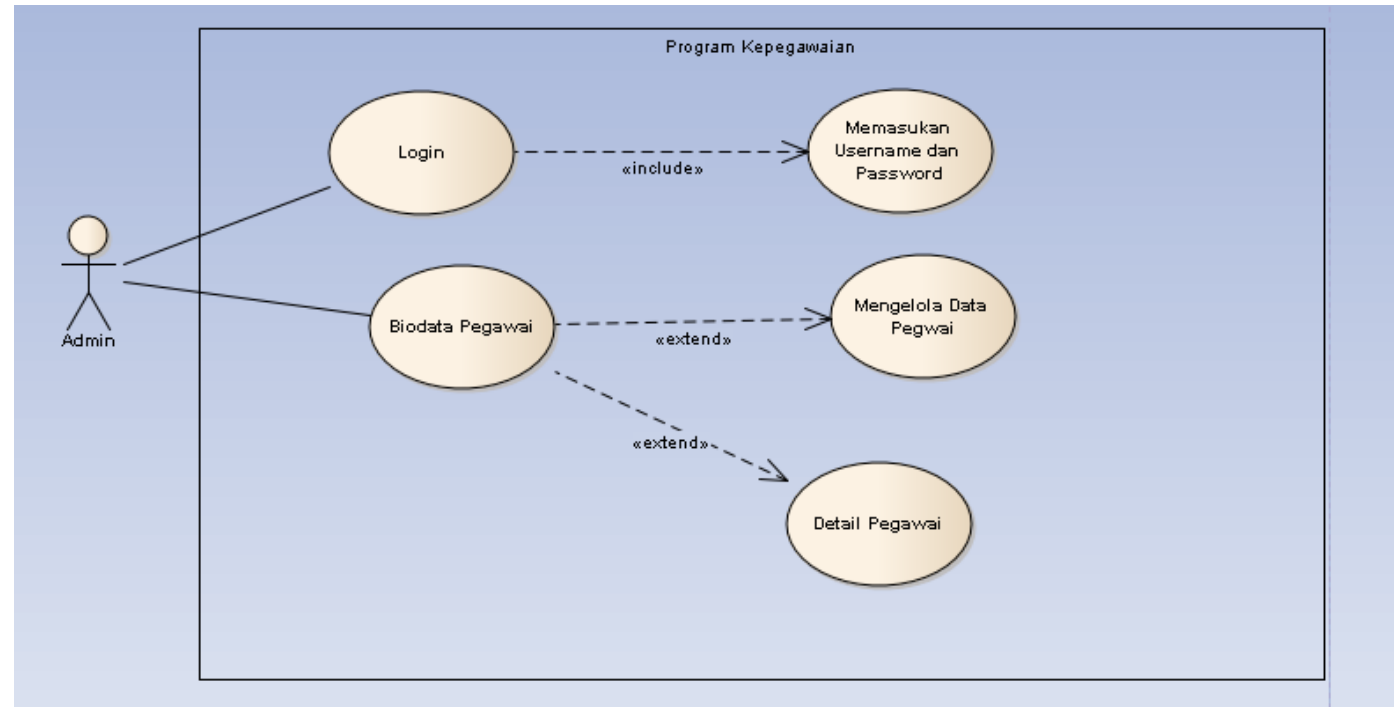

Gambar 2. Use Case Aplikasi Kepegawaian Fakultas Teknik

Aktor yang ada pada sistem ini adalah admin. Admin merupakan operator yang bertugas untuk melakukan manipulasi data kepegawaian baik berupa penambahan, pengurangan ataupun.perubahan data.

\section{B. Class Diagram}

Class Diagram adalah diagram yang menunjukan class-class yang ada dari sebuah sistem dan hubungannya secara logika. Class diagram menunjukkan satu set kelas, interface, dan kolaborasi dan hubungan mereka. Diagram ini adalah diagram yang paling umum ditemukan dalam pemodelan sistem berorientasi objek. Class diagram mengatasi tampilan desain statis dari suatu sistem (The Unified Modeling Language User Guide, 2005). Oleh karena itu, class diagram merupakan tulang punggung atau kekuatan dasar dari hampir setiap metode berorientasi objek termasuk UML. Gambar 3.2 menunjukkan class diagram Sistem Informasi Kepegawaian Fakultas Teknik Universitas Lambung Mangkurat. 
Amalia Maya, Alkaff Muhammad, Sari Yuslena — Rancang Bangun Sistem Informasi Manajemen Kepegawaian Di Fakultas Teknik Universitas Lambung Mangkurat

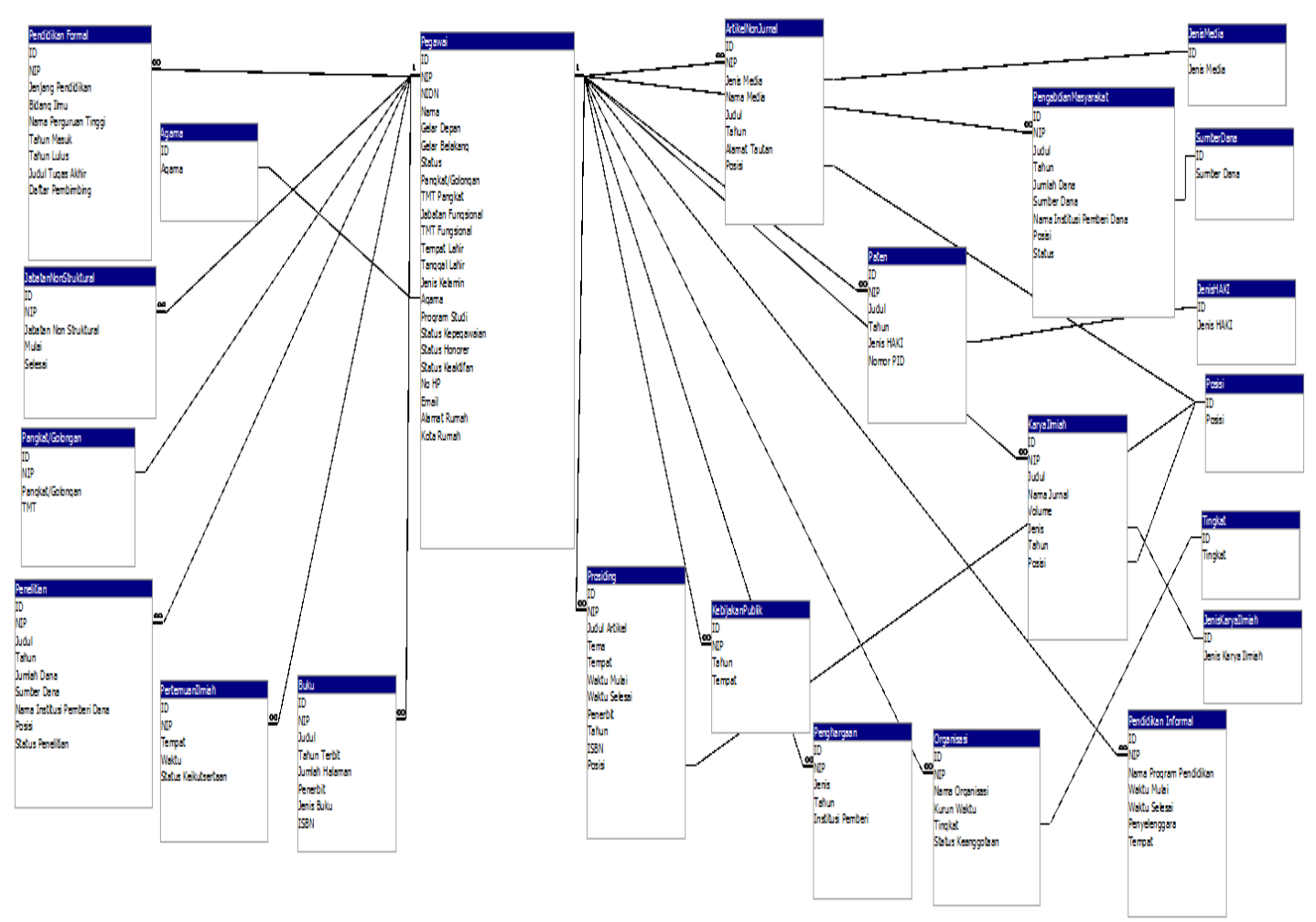

Gambar 3. Class Digram Sistem

Kelas pegawai merupakan kelas utama yang ada di dalam sistem dimana kelas pegawai menampung data utama pegawai. Data tambahan yang perlu ditambahkan seperti nama kota diturunkan ke kelas Kota. Masing-masing kelas memiliki nama yang bersesuaian dengan proses pada use case.

Tampilan sistem informasi kepegawaian Fakultas Teknik Universitas Lambung Mangkurat dapat dilihat pada gambar 4 dibawah ini.

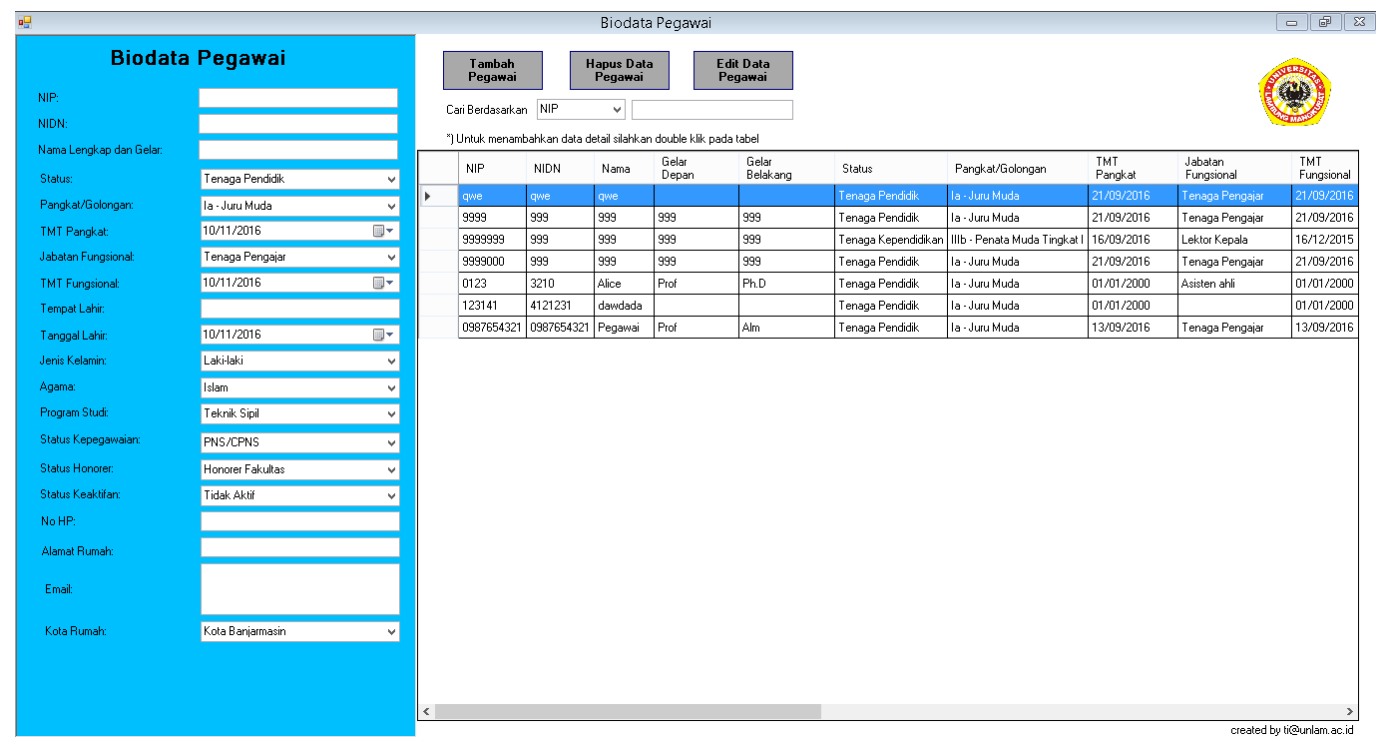

Gambar 4. Tampilan Sistem Informasi Kepegawaian Fakultas Teknik

\section{V. KESIMPULAN}

1. Dengan adanya penerapan sistem informasi manajemen data-data yang terkait dengan tenaga pendidik dan tenaga kependidikan, terutama yang berkaitan dengan data penelitian dan pengabdian masyarakat, proses pendataan di 
JTIULM - Volume 1, Nomor 2, Juli-Desember 2016: 19-24

Fakultas Teknik Universitas Lambung Mangkurat lebih tertata dengan rapi. Data tenaga pendidik dan tenaga kependidikan dapat dengan mudah dicari dan dicetak apabila diperlukan. Hal ini tentunya sangat memudahkan dalam pelaksanaan monitoring dan evaluasi kinerja pegawai di Fakultas Teknik Universitas Lambung Mangkurat.

\section{DAfTar Pustaka}

[1] A. Imron, Administrasi Kepegawaian Negara di Indonesia, Malang: Agritek Pembangunan Nasional, 2008.

[2] D. M. Kroenke, Management Information Systems, New York: McGraw-Hill, Inc., 1990.

[3] R. S. Pressman, Software Engineering: A Practitioner's Approach, Palgrave Macmillan, 2005.

[4] T. B. Raymond, "Integrating Formal Methods by Unifying Abstractions," Springer, vol. 2999, pp. 441-460, 2004.

[5] The Unified Modeling Language User Guide, Pearson Education India, 2005. 